\title{
Effects of High Calcium and Phosphorus Administrations on Secondary Sex Ratio in Pigs
}

\author{
Hiroshi TORIUMI, Shigeo OHBA, Yasushi KUWABARA, \\ Kaoru TAKAGI, Shigehisa TSUMAGARI, \\ and Masatoshi TAKEISHI
}

College of Agriculture and Veterinary Medicine, Nihon University, Fujisawa City, Kanagawa Prefecture, Japan 252

\begin{abstract}
When 19,025 sows were administered with a calcium $(\mathrm{Ca})$ and phosphorus $(\mathrm{P})$ preparation containing 2.55-fold $\mathrm{Ca}$ and 1.54-fold $\mathrm{P}$ of the respective standardized mineral contents for breeders, a significantly $(\mathrm{P}<0.01)$ higher litter male/female ratio (secondary) was indicated in the calcium and phosphorus $(\mathrm{Ca} / \mathrm{P})$ treatment period compared to that of pre-treatment (control) interval. During the pre-treatment period, the litter sex ratio of sows indicated a value similar to previous findings. By supplementing this $\mathrm{Ca} / \mathrm{P}$ preparation in breeders for a 2-year period, the male/female ratio was significantly enhanced without any apparent influences from the breed, mating pattern, seasonal variation and parity history. Further, effects on gestation period and litter size were negligible with supplementation of high $\mathrm{Ca} / \mathrm{P}$ levels. On comparing the male ratio $(1.395$; taking the female ratio as 1$)$ in the post-treatment (1.066) and pre-treatment (0.992) periods, the former interval manifested a significantly higher value, indicating favorable effects of the high $\mathrm{Ca} / \mathrm{P}$ supplementary diet on the male/female ratio. Further, the longer the sows were supplemented with this $\mathrm{Ca} / \mathrm{P}$ preparation, the higher was the male/female ratio. Terminating supplementation of the high $\mathrm{Ca} / \mathrm{P}$ preparation during the post-treatment period manifested a recovery tendency of the male/female ratio to pre-treatment values.

Key words: High calcium/phosphorus supplement, Sex ratio, Pigs.
\end{abstract}

(J. Reprod. Dev. 39: 73-77, 1993)

A ccording to previous reports, the litter sex ratios (secondary sex ratio: male number/litter size) of cows [1] and rats [2] are 51.5 and $49.2 \%$, respectively. With regards to piglets, except for an inbreeding study in 1986 [3], the sex ratios for the past 20 years vary within a narrow margin; from the lowest of $50.9 \%$ [4] to the highest value of $52.4 \%$ [5]. The primary sex ratio appears to score a slightly higher value than the secondary sex ratio [2].

Although the effects of $\mathrm{Ca} / \mathrm{P}$ supplementations on growth performance and soft tissue mineral contents in pigs have been recently examined [7], studies on the effects of these 2 minerals on sex

Accepted for Publication: October 25, 1992

Correspondence: M. Takeishi ratio in pigs are not attempted.

In our present experiment, a rich $\mathrm{Ca} / \mathrm{P}$ preparation was fed to breeder sows in Farm $T$ in Kanagawa prefecture for a period of 2 years. Parameters of breeding performance during pretreatment, treatment and post-treatment periods of high $\mathrm{Ca} / \mathrm{P}$ were compared. Moreover, the influence of high $\mathrm{Ca} / \mathrm{P}$ supplementation on male/ female ratio was evaluated as well.

\section{Materials and Methods}

\section{Sows}

Breeders $(n=401)$ and their ensuing generation (F1) of 19,025 sows were used for the experiment. 
A total of 297 sows (197 Yorkshire, 40 Landrace, 50 Duroc, $10 \mathrm{~F} 1$ sows of Yorkshire $\times$ Landrace breed) sows were fed with a normal standard diet [6] during the pre- $(n=207)$ and post- $(n=90)$ treatment periods with the high $\mathrm{Ca} / \mathrm{P}$ preparation. During the treatment period, 104 cases (52 Yorkshire, 17 Landrace, 32 Duroc, 3 F1 sows of Yorkshire $\times$ Landrace breed) were treated with a diet enriched with high $\mathrm{Ca} / \mathrm{P}$ supplements. Analysis of the dietary contents of the normal diet registered $72.0 \%$ total digestible nutrients (TDN), $12.5 \%$ digestible crude protein (DCP), $15.0 \%$ crude protein (CP), $0.65 \% \mathrm{Ca}$ and $0.5 \% \mathrm{P}$. With regards to the enriched supplemented diet, except for the additional $1.5 \% \mathrm{Ca}$ and $0.78 \% \mathrm{P}$ (supplemented with $\mathrm{CaPO}_{3}$ and $\mathrm{CaCO}_{3}$ ), the rest were of identical composition to the normal diet.

\section{Experimental period}

An experimental period of 8 yr 5 mo (April 21, 1978-September 5, 1986) was allowed for the study. However, supplementation of the high $\mathrm{Ca} / \mathrm{P}$ diet was conducted for only $2 \mathrm{yr}$ (treatment period: October 6, 1982-October 16, 1984), whereas a control period of 4 yr 6 mo (pretreatment period: April 21, 1978-October 5, 1982) and a recovery period of 2 yr (post-treatment period: October 17, 1984-October 5, 1986) were allotted for studying the subjects treated with the normal diet. The recovery tendency in the 2-yr post-treatment period was allotted for comparative and confirmatory purposes.

\section{Methods}

The $\mathrm{Ca} / \mathrm{P}$ preparation was mixed with supplemented standard diet to make an enriched mineral diet. Sows were fed with this high $\mathrm{Ca} / \mathrm{P}$ diet for $2 \mathrm{yr} ; 3 \mathrm{~kg} /$ day during the gestation period followed by $6 \mathrm{~kg}$ /day for the nursing period. Similar feeding schedules were designated for the breeders during the same experimental period. Matings were performed either naturally (144 sows) or artificially (267 sows). Artificial and natural inseminations performed within Farm $T$ were 187 cases, whereas the remaining cases $(n=224)$ were artificially inseminated with sperm from outside sources (total $=411$ ), respectively.

\section{Statistical analysis}

Results were verified with the Student's $t$ test using the pre-treatment values for the respective parameters as controls.

\section{Results}

On studying the effects of $\mathrm{Ca} / \mathrm{P}$ administration during the gestation period, sows of pretreatment, treatment and post-treatment periods registered 115.0, 114.8 and 115.2 days respectively, with neither extension nor shortening of the gestation period (Table 1).

With regards to the litter size, sows produced $9.174 \pm 3.014,8.913 \pm 2.551$ and $10.133 \pm 3.240$ litters during pre-treatment, treatment and posttreatment periods, respectively (Table 1 ).

The change in the male ratio (male number/ litter size; Table 1) of the pre-treatment period from 1978 to 1981 scored the mean values of 0.47 , $0.48,0.52,0.51$ (mean: $0.498 \pm 0.143$ ), respectively. On initiating administration of the $\mathrm{Ca} / \mathrm{P}$ preparation on October 1982, there was an increased

Table 1. Effects of high calcium/phosphorus supplementation on the various items examined

\begin{tabular}{lrcr}
\hline Item & \multicolumn{3}{c}{ Period } \\
\cline { 2 - 4 } & $\begin{array}{c}\text { pre-treatment } \\
(1978 \sim 81)\end{array}$ & $\begin{array}{c}\text { treatment } \\
(1982 \sim 84)\end{array}$ & $\begin{array}{c}\text { post-treatment } \\
(1985 \sim 86)\end{array}$ \\
\hline Number of calving & $2.96 \pm 2.33$ & $2.41 \pm 1.45$ & $2.98 \pm 2.12$ \\
Pregnancy period & $115.03 \pm 1.83$ & $114.85 \pm 2.04$ & $115.24 \pm 1.76$ \\
Litter size & $9.17 \pm 3.01$ & $8.91 \pm 2.55$ & $10.13 \pm 3.24$ \\
Female neonatals & $4.61 \pm 1.95$ & $3.72 \pm 1.48^{* *}$ & $4.90 \pm 1.93$ \\
Male neonatals & $4.59 \pm 1.96$ & $5.19 \pm 2.13^{*}$ & $5.23 \pm 2.40$ \\
Male number/litter size & $0.50 \pm 0.14$ & $0.58 \pm 0.15^{* *}$ & $0.52 \pm 0.14$ \\
Male/female rate & $0.99 \pm 0.73$ & $1.40 \pm 0.92^{*}$ & $1.07 \pm 0.68$ \\
\hline
\end{tabular}

Significant ${ }^{3}$ differences compared to pre-treatment period $\left(*: \mathrm{P}<0.05,{ }^{* *}: \mathrm{P}<0.01\right)$. 
tendency in the male ratio; from the initial value of $0.52,0.56$, to eventually 0.61 (mean: 0.582 \pm 0.145 ). Post-treatment period from 1985 to 1986 indicated mean male ratios of 0.533 and 0.514 , respectively (mean: $0.516 \pm 0.138$ ). Even on viewing the season-sex ratio correlation, no apparent effects on this ratio were elicited by the seasonal factor (Table 1).

With employment of sperm sources outside and within Farm $\mathrm{T}$ for artificial inseminations, the male/female ratios did not indicate any differences with regards to the sperm source. The ratio scores with outside sperm source during the nontreatment period and treatment periods were 1.29 and 0.90 , whereas those using sperm source of Farm $T$ registered 1.32 and 0.89 , respectively. This indicated distinctly the shift to an increased tendency in male/female ratio of the former group was attributed to high $\mathrm{Ca} / \mathrm{P}$ supplementation without any apparent influences from the sperm source.

With regards to breeds, no apparent effects on the male/female ratio were observed. However, on comparing the mineral-supplemented and nontreated sows, respective male/female ratios of 1.32 and 0.89 , were obtained, equilibrating thus a tendency favorable towards the male/female ratio with high $\mathrm{Ca} / \mathrm{P}$ treatment.

With regards to mating patterns (artificial insemination, natural mating), artificial inseminations and natural matings produced 0.91 and 0.82 in the non-treated group against the respective ratios of 1.28 and 1.45 in the $\mathrm{Ca} / \mathrm{P}$-treated sows, portraying the insignificant influences of the mating pattern on the sex ratio.

Parities, gestation periods, litter sizes and sex ratios of sows of the pre-treatment, treatment and post-treatment periods are represented in Table 1 . For corresponding mean parities of 2.963, 2.413 and 2.981, the total litter sizes of $9.199,8.913$ and 10.133 with gestation periods of $115.0,114.8$ and 115.2 days were recorded, respectively. Based on statistical analysis of the respective items, the male/female ratio scored statistical significance of $\mathrm{P}<0.05$.

\section{Discussion}

Differences in sex ratio in litters of sows have been reported; secondary sex ratio ranges from
$50-52 \%[4,5]$, whereas the score was $49.84 \%$ for sows fed on a normal standard diet in our present experiment, a value that is higher than the $49.2 \%$ documented for rats [1] but lower than the $51.52 \%$ in cows [2].

Limited findings on the relationship between sex ratio and gestation period available have indicated the latter varies narrowly within a period of 115 days. In our present study, administrations of the $\mathrm{Ca} / \mathrm{P}$ preparation did not influence the gestation period.

As for the litter size, respective values of $9.199 \pm 3.014,8.913 \pm 2.551$ and $10.133 \pm 3.24$ for pre-treatment, $\mathrm{Ca} / \mathrm{P}$-supplemented, and posttreatment periods were registered without any significant differences. Moreover, seasonal factors were negligible in influencing the litter size, a finding coinciding closely to those of Nishida et al. $[4,5,8]$.

Beside the above factors, the sex ratio was independent of mating pattern (artificial insemination and natural mating). Such a finding, where the difference in sex ratio of artificially inseminated and naturally mated sows is negligible, has been previously documented as well [5, 8-12]. Although there were no differences in sex ratios between sows inseminated with sperm from outside sources and those naturally mated and artificially inseminated with sperm from Farm $T$, an obvious difference in the sex ratio of sows fed with normal standard diet compared to those supplemented with the high $\mathrm{Ca} / \mathrm{P}$ agent was observed.

Previous data [5, 8-12] have indicated that sex ratio is not related to breeds, parity history, gestation period and litter size. Beside these findings, seasonal variations did not indicate any influences on these parameters in our present study as well.

Of the investigation period of 8 yr $5 \mathrm{mo}$, supplementation with 2.55-fold Ca and 1.54-fold $\mathrm{P}$ using the high $\mathrm{Ca} / \mathrm{P}$ preparation was performed for only a 2-yr period. During the period between mating/insemination and parturition, the $\mathrm{Ca}$ and $\mathrm{P}$ levels supplemented were 6.98 and $3.58 \mathrm{~kg}$ per sow, respectively. While relative excesses of $\mathrm{Na}^{+}$ and $\mathrm{K}^{+}$ions favor the birth of males, relative excesses of $\mathrm{Ca}^{2+}$ and $\mathrm{Mg}^{2+}$ ions enhance the female ratio [13]. For sows fed with high $\mathrm{Ca} / \mathrm{P}$ contents, male/litter size ratios were significantly enhanced, indicating the male orientated effects of this mineral preparation on sex ratios. Compared 
to $49.84 \%$ registered in sows during the pretreatment period, the sex ratio of the breeders supplemented with high $\mathrm{Ca} / \mathrm{P}$ feed scored a significantly higher value of $58.25 \%$, indicating favorable effects of the high $\mathrm{Ca} / \mathrm{P}$ supplementary diet on the male/female ratio. The male/female ratio of 1.395 in the mineral-supplemented period was significantly $(\mathrm{P}<0.05)$ higher than that of the pre-treatment period (0.992). This finding may explain the differences observed in ratios of normal control sows by Nishida et al. [2, 5]. Moreover, the longer the sows were supplemented with high $\mathrm{Ca} / \mathrm{P}$ concentrations, the higher the tendency inclined to the male ratio. Terminating supplementation of the high $\mathrm{Ca} / \mathrm{P}$ preparation during the post-treatment period manifested a recovery tendency of the male/female ratio to pre-treatment values. This proportional $\mathrm{Ca} / \mathrm{P}$ male ratio relationship was nullified within the initial 6-month period after terminating the mineral supplementation (during the 2-yr posttreatment period). This confirms that the effect of $\mathrm{C} / \mathrm{P}$ supplementation improves the male/litter size ratio in pigs. According to population surveys conducted in humans by Uda et al. [14], the male/female ratio tends to proportionally depend on the age of the fraternal parent. In pigs, such a phenomenon is not usually observed $[4,5]$. Mice
$[15,16]$ and rats [17] indicate a more favorable sex ratio with higher parity, a tendency that was similarly manifested in our present results where our sows attained a significantly higher sex ratio with enriched $\mathrm{Ca} / \mathrm{P}$ supplementation over a long period. Beside the above factors that have been or were investigated, the sex ratio appears to display a close relationship with the blood $\mathrm{pH}$ value [18-21]. Studies on this sex ratio/blood $\mathrm{pH}$ correlation, and the blood $\mathrm{pH}$ value with respect to excessive $\mathrm{Ca}$ and $\mathrm{P}$ supplementations are currently undertaken in our laboratories.

In general, breeding farms prefer males more than females in terms of achieving better meat quality in the former. However, in the case of Duroc breed, breeders would prefer litter sizes with higher male/litter size ratio for better economic viability. As such, if the sex ratio can be controlled with $\mathrm{Ca} / \mathrm{P}$ supplementation, use of this $\mathrm{Ca} / \mathrm{P}$ preparation would be of much economic benefit to breeders.

\section{Acknowledgement}

The authors wish to thank Dr. Anthony F.W. Foong for reading the manuscript.

\section{References}

1. Johansson I. The sex ratio and multiple births in cattle. Z Tierzucht Zuchtbiol 1932; 24: 183-268 (In German).

2. Nishida $\mathbf{S}$, Nakama $\mathbf{K}$. The sex ratio of offspring in the rat. Japan J Anim Reprod 1971; 17 (2): 74-78 (In Japanese).

3. Solano A. Consanguinity and sex ratio in a closed herd of swine. Genet Iber 1989; 38 (1-2): 111-118 (In Italian).

4. Nishida S, Otsuka J, Sakai R. Secondary sex ratio of swine in the six experimental stations of animal husbandry. Japan J Anim Reprod 1981; 27 (3/4): 137-142 (In Japanese).

5. Nishida S, Otsuka J, Sanada T, Arai T, Kano Y. Sex ratio of offspring in domestic animals: Swine (4). Japan J Anim Reprod 1973; 18(4): 119-126 (In Japanese).

6. Japanese Feeding Standard for swine. In: Agriculture, Forestry and Fisheries Research Council Secretariat (ed.), Ministry of Agriculture, Forestry and Fisheries, Japan: Tokyo Central Association of Livestock Industry; 1987 (In Japanese).

7. Pond WG, Walker EFJr, Kirtland D. Effect of dietary calcium and phosphorus levels from 40 to $100 \mathrm{~kg}$ body weight on weight gain and bone and soft tissue mineral concentrations. J Anim Sci 1978; 46(3): 686-691.

8. Sharma GC, Mishra RR, Bisht GS. Studies on sex-ratio in indigenous pigs. Indian J Anim Res 1991; 25(1): 53-55.

9. Nishida S, Mamba K, Seta S, Otsuka J, Shudo S, Tokoro K. Sex ratio of offspring in domestic animals: Swine (1). Japan J Zootech Sci 1969; 40(11): 449-462.

10. Nishida S, Otsuka J, Saito K. Sex ratio of offspring in domestic animals: Swine (2). Japan J Zootech Sci 1971; 42(2): 71-78 (In Japanese).

11. Nishida S, Otsuka J, Ohashi T, Sugawara K, Yamagishi T. Sex ratio of offspring in domestic animals: Swine (3). Japan J Zootech Sci 1972; 43(4): 
187-192 (In Japanese).

12. Gray E, Kaeanbaf MN. Sex ratio and distribution of sexes in swine. J Hered 1985; 76(1): 36-38.

13. Bolet GLG, Dando $\mathbf{P}$, Ollivier L. Effect on sex ratio of mineral diet in sows. Reprod Nutri Dev 1982; 22(6): 1073-1081.

14. Uda H. Sex ratio and the "sexual age". Jap Jour Genet 1957; 32(2): 48-57.

15. Parkers AS. Studies on the sex-ratio and related phenomena. V-the sex ratio in mice, and its variation. Brit J Exp Boil 1924; 1: 323-334.

16. Parkers AS. Fertility in mice. Brit J Exp Biol 1924; 2: 21-31.

17. King HD. Litter production and the sex ratio in various strains of rats. Anat Rec 1924; 27(5): 337-366.

18. Weir JA, Clark RD. Production of high and low blood-pH lines of mice by selection. J Hered 1956; 27: 125-132.

19. Weir JA. Sex ratio related to sperm source in mice. J Hered 1958; 49: 223-227.

20. Weir JA. A sex ratio factor in the house mouse that is transmitted by the male. Genetics 1960; 45: 1539-1552.

21. Weir JA. Hereditary and environmental influences on the sex ratio of PHH and PHL mice. Genetics 1962; 47: 881-897. 